\title{
FENOMENA KELOMPOK SEL (CELL GROUP) DALAM
}

\section{GEREJA LOKAL}

\author{
Amos Hosea
}

\begin{abstract}
Abstrak
Tulisan ini membahas tentang kelompok sel yang dianggap oleh ahli peneliti pertumbuhan gereja sebagai sebuah fenomena yang menarik untuk diteliti dan diterapkan di dalam sebuah gereja lokal. Di dalam pertumbuhan gereja ditemukan berbagai macam model yang disebut sebagai model pertumbuhan gereja. Tulisan ini membahas tentang kelompok sel secara komprehensif dan bersifat umum yang dimulai dari pembahasan tentang pengertian kelompok sel. Terdapat beberapa defisini yang digunakan untuk menggambarkan pengertian sebuah kelompok sel. Pengertian atau berbagai definisi kelompok sel dibahas secara komprehensif supaya dapat memberikan pengertian yang utuh. Perbedaan antara gereja yang memiliki kelompok sel dengan gereja yang tidak memakai kelompok sel di dalam sebuah gereja lokal digambarkan secara singkat. Untuk lebih memperjelas pengertian kelompok sel, perbedaan antara ibadah umum dengan kelompok sel diulas secara umum. Sejarah kelompok sel mendapat perhatian khusus di dalam tulisan ini. Alasan penerapan kelompok sel bagi sebuah gereja lokal mendapat sorotan khusus. Dan pada akhirnya diulas bagaimana proses dan penerapan sebuah kelompok sel di dalam sebuah gereja lokal.
\end{abstract}

Kata kunci: kelompok sel, gereja lokal, pertumbuhan gereja, multiplikasi

\section{Pendahuluan}

Sejarah pertumbuhan gereja selalu diwarnai dengan banyak gerakan rohani yang terjadi dalam sejarah gereja.1 Salah satu fenomena gerakan rohani yang terjadi di antara gereja-gereja yang bertumbuh di seluruh dunia yang terjadi menjelang

1 Dalam sejarah gereja terjadi berbagai macam gerakan rohani seperti gerakan reformasi, gerakan kekudusan, gerakan Pentakosta, gerakan Karismatik. Namun istilah "gerakan" (movement) yang dipakai akhir abad duapuluh adalah gerakan kelompok sel. Ralph Neighbour, Jr., memberikan fakta bahwa kelompok sel adalah sebuah gerakan rohani yang membawa dampak bagi pertumbuhan gereja seperti yang ditemukan dalam pertumbuhan gereja di Korea Selatan, Jepang, Singapura, Thailand, daratan China, Macau, Hongkong, Afrika, Inggris, Aus-

dalam pengertian ini adalah sebuah kecenderungan, tren yang terjadi dalam gereja. Lihat kamus Webster's Ninth New Collegiate Dictionary, (Springfield: MerriamWebster Inc., Publishers, 1991), 776. 
tralia, Afrika Selatan dan di Amerika Serikat.2

Kelompok sel menjadi sebuah gerakan rohani yang melanda seluruh dunia sampai tulisan ini dibuat ini. Kecenderungan gerejagereja lokal yang bertumbuh di Indonesia, khususnya, gereja-gereja dari kalangan gereja-gereja denominasi Pentakosta/Karismatik membangun pelayanan dengan memakai kelompok sel sebagai bagian terpenting di dalam strategi pertumbuhan gerejanya. Berbagai nama diberikan untuk kelompok sel di berbagai gereja dengan nama-nama yang memberkan ciri khas tersendiri bagi gerejagereja tersebut.

Misalnya, Gereja Bethel Indonesia (GBI) Ecclesia di Taman Semanan Indah, Cengkareng, Jakarta Barat, memberikan nama Ecclesia Family untuk kelompok sel gereja ini. Nafiri Discipleship Church (NDC) Jakarta memiliki kelompok sel dengan memberikan nama CORE (Community of Revival). GBI di bawah penggembalaan Pendeta DR. Ir. Niko Njotoraharjdo memiliki COOL (Community of Love) yang sebenarnya adalah sebuah komunitas kelompok sel.

\section{Pengertian Kelompok Sel}

Seringkali pemahaman kelompok sel berangkat dari pola yang

2Ralph W. Neighbour, Jr., Where Do We Go From Here?, (Houston: Touch Publications, Inc., 1990), 23-24. diterapkan Musa dalam memimpin orang Israel berdasarkan saran dari mertuanya, Yitro, dalam perjanjian lama kitab Keluaran 18:21,"Di samping itu kaucarilah dari seluruh bangsa itu orang-orang yang cakap dan takut akan Allah, orang-orang yang dapat dipercaya, dan yang benci kepada pengejaran suap; tempatkanlah mereka di antara bangsa itu menjadi pemimpin seribu orang, pemimpin seratus orang, pemimpin lima puluh orang dan pemimpin sepuluh orang."

Berdasarkan nasihat Yitro kepada Musa untuk membentuk para pemimpin atas para pemimpin sampai kepada pemimpin dalam kelompok kecil, pola kepemimpinan gereja dengan memakai pola kelompok sel diharapkan membantu seorang pemimpin dalam jemaat supaya kepemimpinan dapat berjalan dengan baik (Keluaran 18:17). Pola kepemimpinan dengan memakai kelompok kecil, seorang pemimpin akan lebih efisien dalam menjalankan tugas-tugas kepemimpinannya (Keluaran 18:18). Dalam kelompok kecil, tugas seorang pemimpin yang penting adalah mewakili umat Tuhan di hadapan Tuhan dan mengajarkan kebenaran dapat diterapkan dengan lebih baik (Keluaran 18:19-20). Pemberdayaan dalam kelompok kecil akan nampak karena penempatan orang-orang yang cakap untuk menjadi pemimpin atas seribu orang, atas seratus orang, atas limapuluh orang, 
dan atas sepuluh orang (Keluaran 18:21). Sehingga dengan pola pelayanan berdasarkan kelompok kecil, maka terbentuklah kerjasama kepemimpinan untuk menyelesaikan berbagai permasalahan di tengah-tengah umat Tuhan (Keluaran 18:22).

Tuhan Yesus pun memakai pola pelayanan bersama dengan kelompok kecil seperti yang digambarkan dalam Markus 3:115, "Ia menetapkan dua belas orang untuk menyertai Dia dan untuk diutus-Nya memberitakan Injil dan diberi-Nya kuasa untuk mengusir setan." Gereja mula-mula juga memiliki pola kelompok kecil di mana jemaat bertemu di rumah-rumah selain mereka bertemu dan beribadah di Bait Allah. Kisah Para Rasul 2:46-47 mengatakan,"Dengan bertekun dan dengan sehati mereka ber-kumpul tiap-tiap hari dalam Bait Allah. Mereka memecahkan roti di rumah masingmasing secara ber-gilir dan makan bersama-sama dengan gembira dan dengan tulus hati, sambil memuji Allah. Dan mereka disukai semua orang. Dan tiap-tiap hari Tuhan menambah jumlah mereka dengan orang yang diselamatkan."

Alkitab hanya memberikan gambaran pola kelompok kecil secara umum. Pengertian kelompok sel hanya dapat dimengerti dari pola atau model kelompok kecil yang dapat ditelusuri dari pola kepe-mimpinan Musa dalam kitab Ke-luaran 18:17-21

3C. Peter Wagner, Your Church Can Grow, (Ventura: Regal Books, 1984), 124. atau pun juga pola pemuridan Tuhan Yesus dalam ke-lompok kecil. Itulah sebabnya pe-ngertian kelompok sel harus men-dapatkan pengertian yang lebih tek-nis seperti beberapa pengertian dari kelompok sel yang digambarkan berikut ini.

Larry Richards, seperti yang dikutip oleh C. Peter Wagner, mengatakan bahwa kelompok sel adalah,"Eight or twelve believers gathered to minister to each other, to grow in their sensed loved and unity, and to encourage one another to full commitment to Christ." (Delapan atau duabelas orang-orang percaya yang berkumpul untuk saling me-layani, bertumbuh di dalam kasih dan kesatuan, dan saling menguatkan satu dengan yang lain untuk me-menuhi komitmen yang utuh kepada Kristus).3 Sedangkan Obaja Tanto Setiawan memberikan pengertian kelompok Sel adalah keluarga secara rohani.4 Sedangkan Joel Comiskey mencoba menggambarkan sebuah kelompok sel sebagai berikut,

Sebuah kelompok kecil yang bertemu setiap minggu untuk saling membangun sebagai anggota tubuh Kristus, dan untuk menyebarkan Injil kepada mereka yang belum mengenal Yesus. Sasaran akhir dari setiap sel

adalah memultiplikasikan dirinya seraya kelompok itu bertumbuh melalui penginjilan dan pertobatan. Dengan demikian ada anggota baru yang ditambahkan ke dalam gereja dan ke dalam kerajaan Allah. Anggota kelompok sel juga didorong untuk menghadiri ibadah raya dari gereja tersebut tempat kelompok sel-

4Obaja Tanto Setiawan, Kelompok Sel Prinsip 12, (Solo: Departemen Media GBI Keluarga Allah, 2000), 25. 
kelompok sel yang ada berkumpul untuk menyembah."5

\section{Perbedaan Gereja Dengan}

\section{Kelompok Sel Dengan Gereja} Tanpa Kelompok Sel

Raplh Neighbour menggambarkan perbedaan antara gerejagereja yang memiliki 


\begin{tabular}{|c|c|c|}
\hline Keterangan & Gereja Dengan Kelompok Sel & Gereja Non-Sel \\
\hline Lokasi & Berpusat di Sel & Berpusat di Gedung Gereja \\
\hline Ukuran Kelompok & Kecil dan Akrab & Besar dan Kurang Akrab \\
\hline Aktifitas Rohani & Setiap Hari (Informal) & Mingguan (Formal) \\
\hline Jika Ada Masalah & Saling Menguatkan & Mencari Pendeta \\
\hline Pembinaan & Membagi hidup & Perpindahan Pengetahuan \\
\hline Kehidupan Doa & Sangat Ditekankan & Sangat Terbatas \\
\hline Tugas Pemimpin & Setiap Orang Dilengkapi & Membuat Program Gereja \\
\hline Tugas Gembala & Menjadi Teladan & Pengkhotbah yang Baik \\
\hline Gol bagi Jemaat & Melayani yang Lain & Kehadiran yang Setia \\
\hline Pelayanan Jemaat & Semua Melayani & Tidak Semua Melayani \\
\hline Pengajaran & Penekanan Praktek & Penekanan pada Doktrin \\
\hline Karunia Rohani & Dipraktekkan & Hanya pada Pengerja \\
\hline Kegiatan Gereja & Di Sel \& Ibadah Minggu & Banyak Kegiatan Gereja \\
\hline Penginjilan & Melalui Komsel & Membuat KKR Besar \\
\hline Pertumbuhan & Pertumbuhan Pertobatan & Pertumbuhan Biologis \\
\hline SDM Gereja & Dari Dalam Gereja & Bergantung Dari Luar \\
\hline
\end{tabular}


kelompok sel dengan gereja-gereja yang tidak memakai pola kelompok

Obaja Tanto Setiawan memberikan perbedaan antara ibadah dalam kelompok sel dengan pola ibadah sel di dalam pengembangan gerejanya, ${ }^{6}$

Umum seperti Persekutuan Doa, Pendalaman Alkitab, Doa Malam, dan sebagainya yakni berikut ini:

\begin{tabular}{|l|l|}
\hline Ibadah Umum & Kelompok Sel \\
\hline $\begin{array}{l}\text { Dapat terlepas dari sebuah gereja lokal. } \\
\text { Kadang bersifat oikumene seperti Per- } \\
\text { sekutuan Doa. }\end{array}$ & $\begin{array}{l}\text { Tidak dapat lepas dari gereja lokal } \\
\text { karena salah satu tujuannya adalah } \\
\text { meningkatkan penggembalaan. }\end{array}$ \\
\hline $\begin{array}{l}\text { Cenderung untuk menjadi besar secara } \\
\text { jumlah dan jika itu adalah sebuah } \\
\text { persekutuan doa, maka dapat menjadi } \\
\text { sebuah gereja baru. }\end{array}$ & $\begin{array}{l}\text { Cenderung kelompok selnya yang makin } \\
\text { banyak. Jika ada penambahan, maka sel } \\
\text { harus berbelah menjadi komsel yang } \\
\text { baru di dalam gereja. }\end{array}$ \\
\hline $\begin{array}{l}\text { Datang hanya untuk mendengar seorang } \\
\text { pengkhotbah. Jadi harus ada seorang } \\
\text { pengkhotbah yang baik dalam ibadah. }\end{array}$ & $\begin{array}{l}\text { Tidak datang hanya untuk mendengar } \\
\text { khotbah tetapi semua anggota terlibat } \\
\text { dalam "sharing” firman Tuhan. Pe- } \\
\text { mimpin sel tidak harus seorang } \\
\text { pengkhotbah. }\end{array}$ \\
\hline $\begin{array}{l}\text { Ibadahnya hanya satu arah. Dari mimbar } \\
\text { ke arah jemaat. }\end{array}$ & $\begin{array}{l}\text { Ibadahnya melibatkan semua jemaat dan } \\
\text { tidak didominasi oleh satu atau dua } \\
\text { orang saja. }\end{array}$ \\
\hline
\end{tabular}

${ }^{6}$ Ralph Neighbour, Where Do We Go From Here?, (Houston: Touch Publications, Inc., 1990), 58. 
Sejarah Kelompok Sel

Gerakan kelompok sel di-mulai pada akhir abad ke-18, Wesley telah berhasil mengembangkan lebih dari 10.000 kelompok sel yang disebut kelas. Ratusan ribu orang ikut serta di dalam sistem kelompok kecilnya. Wesley menekankan ke-ikutsertaan petobat baru di dalam kelompok kecil dari pada sekedar mengambil keputusan untuk percaya. Wesley akan berkhotbah dan meng-undang orang-orang untuk ber-gabung di dalam kelas.7

David Yonggi Cho, sebagai gembala sidang gereja yang di-anggap memiliki memimpin gereja lokal terbesar di dunia, seringkali dianggap sebagai perintis kegerakan sel modern. Gereja ini telah menjadi gereja lokal terbesar di dunia dengan memiliki 23.000 kelompok sel dan 7 kali ibadah pada hari Minggunya pada era tahun 1990-an.8

Yonggi Cho memulai kelom-pok selnya pada tahun 1964. Dalam lima tahun pertama tanpa kelompok sel, gerejanya telah bertumbuh men-jadi 3.800 jemaat. Pada September 1980, jumlah jemaat sudah mencapai 141.000 orang dengan kecepatan per-tumbuhan mencapai rata-rata 140 orang setiap hari.

Visi kelompok sel dimulai ketika Yonggi Cho mengalami sakit yang cukup parah dan ia tidak dapat berkhotbah dan melayani sebagai gembala secara efektif. Ketika ia ter-baring sakit, Yonggi Cho bergumul dan Roh Kudus berbicara dalam hati-nya,"Biarlah umat-Ku pergi dan bertumbuh." Kalimat itu membuat ia menemukan prinsip di dalam Efesus 4:11-

${ }^{7}$ Joel Comiskey, Ledakan Ke-lompok Sel, (Jakarta: Metanoia, 1998), 24.

8Joel Comiskey, Ledakan Ke-lompok Sel, (Jakarta: Metanoia, 1998), 25.
12. Selanjutnya ia membaca Kisah Para Rasul 2:46-47 yang me-nyatakan ada dua model persekutuan di dalam gereja mulamula. Para murid bersekutu di Bait Allah dan juga di rumah-rumah. Kebenaran ini yang menjadi dasar pelayanan ke-lompok sel di gerejanya.9

Sejak David Yonggi Cho memulai pelayanan kelompok sel-nya, banyak gembala sidang lainnya telah mengikuti jejaknya. Bahkan beberapa gereja membuat modi-fikasi model kelompok sel. Seperti sebuah gereja dari Singapura adalah Faith Community Baptist Church, didirikan oleh Lawrence Khong. Khong memulai gerejanya pada tahun 1986 dengan 600 anggota. Pada tanggal 1 Mei 1988, dengan bantuan dari Ralph Neighbour, Jr., gereja itu direstruk-turisasi menjadi gereja sel sepenuh-nya. Pada dekade 1990-an gereja ini memiliki 7.000 anggota dengan 500 kelompok sel yang aktif. Pola kelompok ini seringkali membedakan antara gereja sel dengan gereja yang memiliki kelompok sel.10

Cesar Castellanos dari International Charismatic Mission di Bogota, Kolumbia, juga terpengaruh oleh pola kelompok selnya di Korea. Namun ia lebih jauh mengembang-kan pola yang disebut dengan G-12 Model atau dikenal di Indonesia dengan istilah Prinsip-12.

Pemahaman G-12 atau Grati-vity12 diilhami oleh hukum gravi-tasi Newton yang melihat sebuah apel jatuh ke bawah. Dan ia melihat kesamaan ketika Tuhan Yesus ber-sama ke-12 murid-Nya. Ia bertanya mengapa bukan 13? Mengapa Tuhan Yesus tidak memuridkan banyak orang? Kemudian Castellanos mem-baca

9Joel Comiskey, Ledakan Kelom-pok Sel, (Jakarta: Metanoia, 1998), 26.

10Joel Comiskey, Ledakan Kelom-pok Sel, (Jakarta: Metanoia, 1998), 26. 
Matius 9:35-10:1, dan ia di-yakinkan kebenaran ini.11

Joel Comiskey menemukan fakta delapan gereja yang bertumbuh di dunia adalah gereja-gereja yang menggunakan kelompok sel sebagai ujung tombak pelayanan mereka.12 Beberapa gereja tersebut adalah (1)Bethany World Prayer Center di Baker, LA, Amerika Serikat, memiliki lebih dari 7.000 jemaat dengan lebih 500 kelompok sel. (2)Gereja The Christian Center of Guayaquil di Ekuador, Amerika Selatan, memiliki jemaat lebih dari 7000 anggota dan dengan lebih 2.000 kelompok sel. (3)Elim Church di San Salvador dengan jumlah kelompok sel se-banyak 5.500 kelompok sel dan 35.000 jemaat. (4)Faith Community Baptist Church, Singapura, memiliki lebih dari 500 kelompok sel dan lebih dari 6.500 jemaat. (5)The International Charismatic Mission, Bogota Columbia, memiliki 13.000 kelompok sel dengan jumlah jemaat lebih dari 35.000 jemaat. (6)Love Alive Church, Tegucigalpa, Hondu-ras, memiliki lebih dari 1.000 ke-lompok sel dan 7.000 jemaat. (7)Living Water Church, Lima, Peru, terdiri dari 600 kelompok sel dan lebih dari 7.000 jemaat. (8)Yoido Full Gospel Church, Seoul, Korea Selatan, memiliki 23.000 kelompok sel dan jumlah jemaat yang berjumlah 153.000 jemaat.

Di Indonesia salah satu gereja yang secara konsisten dan mem-berikan pengaruh kepada banyak gereja beraliran Pentakosta dan Karismatik dalam gerakan kelompok sel adalah Gereja Bethel

11Joel Comiskey, Ledakan Kelom-pok Sel, (Jakarta: Metanoia, 1998), 26.

12Joel Comiskey, Ledakan Kelom-pok Sel, (Jakarta: Metanoia, 1998), 15.

13Bandingkan dengan tulisan Obaja Tanto Setiawan, Kelompok Sel Prinsip 12, (Solo: Departemen Media GBI Keluarga Allah, 2000). GBI Keluarga Allah, Solo, Jawa Tengah, setiap tahun mengadakan konferensi gereja sel yang mengundang gereja-gereja dalam dan luar negeri
Indonesia (GBI) jemaat Keluarga Allah yang berada di kota Solo, Jawa Tengah.13 Hal ini menjadikan GBI Keluarga Allah menjadi semacam pusat studi bagi gerejagereja di seluruh Indo-nesia untuk mengembangkan jemaat dengan memakai kelompok sel sebagai strategi utama dalam per-tumbuhan gereja. Gereja ini sudah memiliki lebih dari 1000 kelompok sel pada tahun 2010.14

David Yonggi Cho dianggap sebagai pelopor kegerakan kelompok sel dalam gereja masa kini yang memberikan pengaruh luas kepada banyak gereja di dunia. Kegerakan rohani dan pertumbuhan gerejanya dalam pelayanan penggembalannya yang terpusat dalam kelompok sel menyebabkan gereja lokalnya di-anggap sebagai gereja lokal terbesar di dunia yang pernah ada dalam sejarah Kekeristenan.15 Menurut pernyataan David Yonggi Cho, "Se-tiap kelompok sel menjadi pusat kebangunan rohani bagi tetangga se-kitarnya, sebab dalam kelompok itu terdapat kehidupan yang sebenar-nya."16

David Yonggi Cho dalam tulisannya, Kelompok Sel Yang Ber-hasil, memberikan banyak kesaksian pribadi yang mengungkapkan pe-nemuan kelompok sel dalam ge-rejanya, pergumulan yang dialami-nya untuk memulai kelompok sel dalam gereja yang digembalakannya, dan beberapa nasihat penting yang David Yonggi Cho bagikan jika sebuah gereja ingin memulai ke-lompok sel dalam sebuah

untuk mempelajari prinsip-prinsip pelayanan kelompok sel.

14Wawancara dengan Megawati Guntur, ketua bidang Penelitian dan Pengembangan Kelompok Sel GBI Keluarga Allah, Solo, Jawa Tengah, 24 September 2010.

15Joel Comiskey, Ledakan Kelom-pok Sel, (Jakarta: Metanoia, 1998), 59.

16David Yonggi Cho, Kelompok Sel Yang Berhasil, (Malang:Gandum Mas, 1994), 58. 
gereja.17 Penemuan dan pengalaman David Yonggi Cho menjadi sangat berharga bagi banyak gereja di dunia untuk mengembangkan bahkan memodifi-kasi berbagai model penerapan ke-lompok sel dalam pelayanan Kristen. Tercatat pelayanan peng-gembalaan Lawrence Khong berhasil menum-buhkan gerejanya di Singapura karena memodifikasi pelayanan ke-lompok sel dari model kelompok Sel David yonggi Cho.

Bahkan gereja International Charismatic Missions yang berada di Bogota, Columbia, Amerika Selatan, memiliki jumlah kelompok sel ter-banyak di dunia karena gembala seniornya, Cesar Castellanos, belajar langsung ke gereja Yiodo Full Gos-pel Church, Seoul, Korea Selatan, yang dipimpin oleh David Yonggi Cho. 18

Ralph Neighbour, Jr., yang membantu Lawrence Khong di Singapura dalam mengembangkan gereja Faith Community Baptist Church menjadi gereja yang me-miliki lebih dari 500 kelompok sel, menulis buku tentang pelayanan kelompok sel yang membahas ber-bagai macam pokok penting dalam pelayanan kelompok sel.

Tulisan Ralph W. Neighbour, Jr., yang berjudul, Where Do We Go From Here?, sering dijadikan se-bagai buku pegangan dalam gereja untuk pelayanan kelompok sel karena buku ini membahas secara komprehensif berbagai topik tentang kelompok sel. Buku ini berbeda dengan tulisan David Yonggi Cho yang lebih bersifat subyektif karena tulisan David Yonggi Cho cenderung membagikan

17David Yonggi Cho, Kelompok Sel Yang Berhasil, (Malang:Gandum Mas, 1994), 58.

18Joel Comiskey, Ledakan Kelom-pok Sel, (Jakarta: Metanoia, 1998), 27. pengalaman penggem-balaan gereja Yoido Full Gospel Church, Seoul, Korea Selatan, yang digembalakannya. Neighbour, Jr., membahas kelompok sel dengan perspektif yang lebih obyektif, men-dasar dan praktis dalam berbagai aspek tentang kelompok sel. Tulisan Neighbour, Jr., memang bertujuan menjadi buku pegangan yang leng-kap untuk pelayanan kelompok sel. Itulah sebabnya tulisannya terbagi dalam tiga kategori utama yaitu situasi masa kini dalam gereja yang memperlihatkan perkembangan ge-reja yang ditopang dengan pelayanan kelompok sel. Kemudian dibahas tentang konsep pemikiran yang mendasari mengenai kelompok sel dalam gereja yang pada akhirnya ditutup dengan hal-hal teknis dalam pelayanan kelompok sel.19

\section{Mengapa Kelompok Sel?}

Berdasarkan hasil riset Chris-tian A. Schwarz terhadap lebih dari seribu gereja di tigapuluhdua negara dan di lima benua selama kurang lebih sepuluh tahun menemukan delapan prinsip penting bagi per-tumbuhan gereja.20 Riset Christian A. Schwarz dianggap sebagai salah satu penelitian pertumbuhan gereja yang sangat luas cakupannya di seluruh dunia. Penelitiannya ingin menarik sebuah benang merah dari berbagai macam model pertumbuhan gereja di seluruh dunia. Schwarz ingin menemukan prinsip-prinsip universal yang membuat gereja di seluruh dunia. Dengan kata lain, Schwarz mengatakan prinsip-prinsip ini jika diterapkan di berbagai tempat dan

19Ralph Neighbour, Where Do We Go From Here?, (Houston: Touch Publications, Inc., 1990), 15.

20Christian A. Schwarz, Pertum-buhan Gereja Yang Alamiah, (Jakarta: Metanoia, 1996), 15-48. 
denominasi gereja di seluruh dunia, maka gereja secara alamiah akan mengalami pertumbuhan.

Schwarz di dalam penelitian-nya menemukan delapan prinsip pertumbuhan gereja. Kedelapan prinsip bagi pertumbuhan gereja ada-lah pertama, kepemimpinan yang melakukan pemberdayaan. Kedua, pelayanan yang berorientasi pada karunia. Ketiga, kerohanian yang haus dan penuh antusiasme. Ke-empat, struktur pelayanan yang tepat guna. Kelima, ibadah yang mem-bangkitkan inspirasi. Keenam, kelompok kecil yang menjawab ke-butuhan secara menyeluruh. Ke-tujuh, penginjilan yang berorientasi pada kebutuhan. Kedelapan, hu-bungan yang penuh kasih.

Memang untuk memahami lebih jelas kedelapan prinsip per-tumbuhan gereja yang ditemukan oleh Schwarz seharusnya diuraikan satu-persatu dari kedelapan prinsip penting bagi pertumbuhan gereja yang ditemukan oleh Schwarz. Namun dari delapan prinsip yang ditemukan dari gereja-gereja yang bertumbuh itu, Schwarz berkata,"Seandainya kita harus me-ngenali satu prinsip mana saja sebagai 'yang paling penting,' maka tanpa ragu prinsip itu adalah pelipatgandaan kelompok-kelompok kecil."21 Hasil penelitian Schwarz mengatakan bahwa pemimpin dari gerejagereja yang bertumbuh cen-derung untuk selalu mendorong multiplikasi kelompok kecil melalui pembelahan sel.22 Itulah sebabnya kelompok sel memberikan dampak bagi pertumbuhan gereja karena prinsip-prinsip penting dari per-tumbuhan gereja terakumulasi dalam multiplikasi

21Christian A. Schwarz, Pertum-buhan Gereja Yang Alamiah, (Jakarta: Metanoia, 1996), 32. kelompok sel. di dalam pengembangan gerejanya, 23

\section{Pengembangan Kelompok Sel}

Pengembangan Kelompok Sel seringkali digambarkan seperti pembelahan sebuah struksul sel digambarkan sebagai berikut,

1. Tahap Belajar. Awalnya setiap sel tubuh manusia sama seperti segumpal protoplasma. Hampir setiap bagian tidak dapat dibeda-kan. Walaupun sel tersebut me-miliki kode genetik untuk ber-multiplikasi, namun sel itu harus tumbuh dan berkembang dahulu. Kelompok kecil memiliki pola yang sama. Para anggota pada awalnya saling memandang dengan keinginan yang tidak di-ketahui dan tahapan pertama dari kehidupan kelompok sel ditandai dengan para anggota yang saling mengenal satu dengan yang lain. Tahap belajar ini kira-kira berlangsung selama satu bulan.

2. Tahap Mengasihi. Kromosom dalam tubuh manusia akhirnya mulai berpasangan, meskipun tidak membentuk garis lurus. Dalam pola serupa, para anggota sel mulai membuka topeng mereka dalam tahap mengasihi ini. Tahap mengasihi akan ber-langsung juga sekitar satu bulan.

3. Tahap Berhubungan. Di dalam sel manusia, kromosom yang tadinya bebas bergerak tiba-tiba mulai membentuk suatu garis di tengah-tengah sel. Di tengah-tengah kelompok sel-kira-kira pada bulan ketiga dan keempat-para anggota mulai menemukan peran mereka. Pada tahap ini me-rupakan tahap yang tepat bagi pelatihan

22Christian A. Schwarz, Pertum-buhan Gereja Yang Alamiah, (Jakarta: Metanoia, 1996), 33.

23Neighbour, opcit., 58. 
penginjilan melalui ke-lompok sel. Tahap ini pun kira-kira berlangsung selama satu bulan.

4. Tahap Peluncuran. Untaian kro-mosom itu mulai berbaris dalam posisi timurbarat, bersiap untuk meluncur dan membuat duplikat yang serupa dengan dirinya. Pada titik ini di dalam kelompok sel, para anggota berfokus pada penginjilan. Walaupun sel itu sering melakukan pengjangkauan, saat peluncuran menunjukkan bahwa penginjilan kelompok sel merupakan aktivitas utama. Tahap peluncuran ini terjadi mulai bulan keempat sampai sel itu bermultiplikasi.

5. Tahap Perpisahan. Ketika satu sel untuk melahirkan sel lain yang identik, kromosom memisahkan diri dan akhirnya bermultiplikasi. Di dalam kelompok sel, para pe-mimpin kelompok sel yang baru dibangkit dan dilatih untuk me-mimpin sel bersamaan dengan masuknya para anggota baru. Ketika kelompok sel tersebut sudah cukup besar, multiplikasi terjadi. Tahap perpisahan ini bisa berlangsung sampai satu tahun.

\section{Praktek Kegiatan Kelompok Sel}

Walaupun ada banyak variasi praktek atau penerapan sebuah kelompok sel, pada umumnya sebuah kelompok sel menjalankan agenda pertemuannya yang seringkali di-singkat dengan singkatan $4 \mathrm{~S}$ dalam pertemuan kelompok sel, yaitu, ${ }^{24}$

\section{Suasana (Pencair Suasana)}

Dinamika rohani: manusia kepada manusia. Dapat berupa permainan yang mendobrak kekakuan di awal pertemuan. Supaya dapat saling mengetahui nama-nama orang-orang yang hadir di dalam komsel.

\section{Sembah (Pujian dan Penyem-bahan)}

Dinamika rohani: manusia kepada Allah. Pujian yang bersifat hori-zontal yaitu pujian yang me-rasakan kesatuan Tubuh Kristus. Penyembahan yang bersifat ver-tikal yaitu penyembahan yang menyenangkan hati Tuhan.

\section{Sharing (Membagi Firman Tuhan)}

Dinamika rohani: Allah kepada manusia. Setiap orang membagi-kan dan mempunyai komitmen untuk menerapkan firman Tuhan di dalam hidupnya. Dapat berupa bahan pelajaran yang sudah ditentukan dari gereja. Dapat berupa bahan khotbah hari Minggu yang diaplikasikan di dalam hidup sehari-hari. Aplikasi firman Tuhan: Dicatat, Direnung-kan, Dilakukan, Diceritakan (4D).

4. Sasaran (Pelayanan dan Pengutusan) Dinamika rohani: manusia kepada manusia yang lainnya. Menerap-kan fungsi Kelompok Sel (4M) yaitu Memelihara, Membangun, Menyatukan, dan Menyelamatkan jiwa-jiwa bagi Kristus.

\section{Kesimpulan}

Pengembangan gereja lokal dengan memakai strategi melalui kelompok sel dapat menjadi sebuah alternatif bagi pertumbuhan sebuah gereja lokal baik secara kualitatif maupun secara kuantitatif. Namun pengembangan gereja melalui kelompok sel adalah sebuah model dari begitu banyak model pengembangan gereja lokal. Esensi pengembangan gereja yang sesuai dengan prinsip-prinsip Alkitab adalah

${ }^{24}$ Obaja Tanto Setiawan, opcit., 32-33. 
faktor yang fundamental bagi pengembangan gereja. Tanpa penerapan dari prin-sip-prinsip Alkitab sebuah gereja lokal tidak akan mencapat pertum-buhan yang sehat sebagai sebuah institusi Ilahi.

Kelompok sel yang menun-jang pertumbuhan gereja lokal harus dimulai dari kepemimpinan rohani yang sehat. Gereja-gereja lokal yang berhasil menerapkan pengembangan gereja melalui kelompok sel selalu diwarnai dengan visi kepemimpinan gereja yang jelas dan konsisten untuk mengembangkan gereja melalui kelompok sel. Tanpa kepemimpinan yang tangguh di dalam pengem-bangan gereja melalui kelompok sel, sebuah gereja lokal akan menemui kesulitan di dalam prinsip multi-plikasi kelompok sel yang merupa-kan kunci pertumbuhan gereja lokal.

\section{Daftar Pustaka}

Alkitab. Lembaga Alkitab Indonesia, 2005.

Cho, David Yonggi. Kelompok Sel Yang Berhasil. Malang:Gandum Mas, 1994.

Comiskey, Joel. Ledakan Kelompok Sel. Jakarta: Metanoia, 1998. Groups of 12. Houston, Touch Publications, 1999.

Menuai Tanpa Batas, Jakarta: Metanoia, 2002.

Donahue, Bill. Membimbing Kelompok Kecil Untuk Mengubah Hidup, Jilid 1, Yogyakarta: Gloria Gaffa, 2010
, Membimbing Kelompok Kecil

Untuk Mengubah Hidup, Jilid 2, Yogyakarta: Gloria Gaffa, 2010.

Go, Mary. Dinamika Kelompok. Malang: Seminari Alkitab Asia Tenggara, 1999.

Kamus Besar Bahasa Indonesia.

Jakarta: Departemen Pendidikan dan Kebudayaan RI, 1993.

Neighbour, Jr., Ralph W. Where Do We Go From Here?, Houston: Touch Publications, Inc., 1990.

Peterson, Jim. Gereja Tanpa Tembok. Jakarta: Pionir Jaya, 2009.

Setiawan, Obaja Tanto. Kelompok Sel Prinsip 12. Solo: Departemen Media GBI Keluarga Allah, 2000.

Pertumbuhan Tanpa Batas, Solo: El Shadday Media Corp., 2005.

Stanley, Paul D.dan Clinton, J. Robert. Mentor. Malang: Gandum Mas, 2001.

Schwarz, Christian A. Pertumbuhan Gereja yang Alamiah. Jakarta: Metanoia, 1996.

Schwarz, Christian A dan Schalk, Christoph. Pedoman Praktis Pertumbuhan Gereja Alamiah. Jakarta: Metanoia, 2002.

Webster's Ninth New Collegiate Dictionary. Springfield: MerriamWebster Inc., Publishers, 1991. 


\section{Biodata Penulis}

Amos Hosea adalah Dosen dibidang Teologi Praktika, khususnya yang berhubungan dengan Teologi Kependetaan bidang Misiologi. Men-jadi Dosen penuh waktu di STTBI dahulu ITKI. Pernah menjabat sebagai Ketua Fakultas Misi Institut Teologi dan Keguruan Indonesia, dan pernah menjabat sebagai Ketua Progam Studi Teologi. Sekarang ini aktif sebagai Dosen tetap Progam Sarjana Progam Studi Teologi Ke-pendetaan. Dan sekarang menjadi Gembala GBI Ebenhaezer, Jakarta. 